\title{
Investigation of the chemical composition, characterization and determination of energy content for renewable energy source (biodiesel) produced from non-edible Ethiopian seeds' particularly castor seed (Ricinus communis) using homogeneous catalysis
}

\author{
Tsegay Hiwot \\ Department of Chemistry, Dilla University, Dilla, Ethiopia
}

\begin{abstract}
Biodiesel is a clean, renewable, biodegradable, environmentally benign, energy efficient and diesel substituent fuel used in diesel engine. It provides a feasible solution to the twin crises of fossil fuel depletion and environmental pollution. It is produced from renewable sources such as vegetable oils or animal fats by trans-esterification. Although this fuel has gained worldwide recognition for many years, it is not being widely commercialized like petroleum diesel in the world, not widely produced and used especially in our country Ethiopia. Analysis of fatty acid methyl ester composition of the biodiesel produced from castor oil was done with the help of GC-MS and 8 fatty acid methyl esters were identified. Acid and base catalyzed methods were used in the synthesis of biodiesel from castor seed oil. In addition to this the variables that affect the amount of methyl ester yield were determined and an optimum of $96.7 \%$ fatty acid methyl ester (FAME) conversion was obtained at a methanol to oil molar ratio of $6: 1,1.0 \%$ mass $\mathrm{NaOH}, 65^{\circ} \mathrm{C}$ reaction temperature and 3 hour reaction time. The energy content of the oil and biodiesel were $39 \mathrm{MJ} / \mathrm{Kg}$ and $40.7 \mathrm{MJ} / \mathrm{Kg}$ respectively which is determined by bomb calorimeter. Other physicochemical properties of the biodiesel were determined and all these lie within the ASTM and EN biodiesel standards except kinematic viscosity. Therefore, castor seed oil methyl ester could be used as an alternative energy resource in diesel engine by blending with petroleum diesel.
\end{abstract}

Keywords: castor oil; non -edible oil; biodiesel; trans-esterification; homogeneous catalyst; FAME; GC-MS

\section{INTRODUCTION}

Biodiesel is a clean, renewable, biodegradable, environmentally benign, energy efficient and diesel substituent fuel used in diesel engine. It is a carbon neutral fuel because there is no overall increase in $\mathrm{CO}_{2}$ in the atmosphere due recycling by the growing plants used to feed the biodiesel industry [1].

Emissions of $\mathrm{SO}_{2}, \mathrm{SO}_{3}, \mathrm{CO}$, un burnt hydrocarbons and particulate matter are lower than that of petroleum diesel [2,3]. 
It is produced by the trans-esterification of triglycerides. Trans-esterification is a threestep reversible reaction of vegetable oils or animal fats with a methanol to form fatty acid methyl esters (FAMEs) and glycerol as a final product [4].<smiles>[R]C(=O)OCC(COC([R4])=O)OC([R])=O</smiles>

Triglyceride (oil)

Figure 1. Base catalyzed trans-esterification processes.

The reaction mechanism for the formation of fatty acid methyl esters (FAME) is described as follows.

\section{1 \\ $3 \mathrm{CH}_{3} \mathrm{OH}+3 \mathrm{~B}^{-} \longrightarrow 3 \mathrm{BH}^{+}+3 \mathrm{CH}_{3} \mathrm{O}^{-}$ \\ Methanol \\ Base \\ conjugate acid \\ Methoxide ion}

Methanol is the most frequently used alcohol for trans-esterification because of its low cost, highest polarity and the corresponding smallest size of the alkoxide group.

Basic and acidic substances can be used as catalysts for trans-esterification. The basic catalysts used for trans-esterification are hydroxides and alkoxides [5]. The most common acidic catalysts used are $\mathrm{H}_{2} \mathrm{SO}_{4}, \mathrm{H}_{3} \mathrm{PO}_{4}$ and $\mathrm{HCl}[5,6]$.

Currently, about $84 \%$ of the world biodiesel production is met by rapeseed oil [7]. The remaining portion is from sun flower oil $(13 \%)$, palm oil $(1 \%)$, soybean and others $(2 \%)$ [8]. since more than $98 \%$ of the biodiesel is made from edible oil, there are many claims due to the depletion of edible oil supply worldwide. Therefore in order to overcome these devastating phenomena, the feed stock for the biodiesel production must be replaced by non edible oil. One such oil would be castor seed oil which is derived from castor plant. Castor oil, Ricinus communis is a member of the tropical spurge family, Euphorbiaceae, Genus: Ricinus and Species: communis. Castor is amongst the plants with the highest oil yield potential because of its high yield of seeds and the high oil content of its seeds. It may be possible to obtain a maximum of $2000 \mathrm{~kg}$ oil $/$ ha [9] where as rape seed produces about 1000 $\mathrm{kg}$ oil /ha and soy bean only produces about $500 \mathrm{~kg}$ oil /ha [10]. Therefore, castor oil is a promising biodiesel source because of its highest oil yield potential, non-edible as a result it does not compete with food security. 


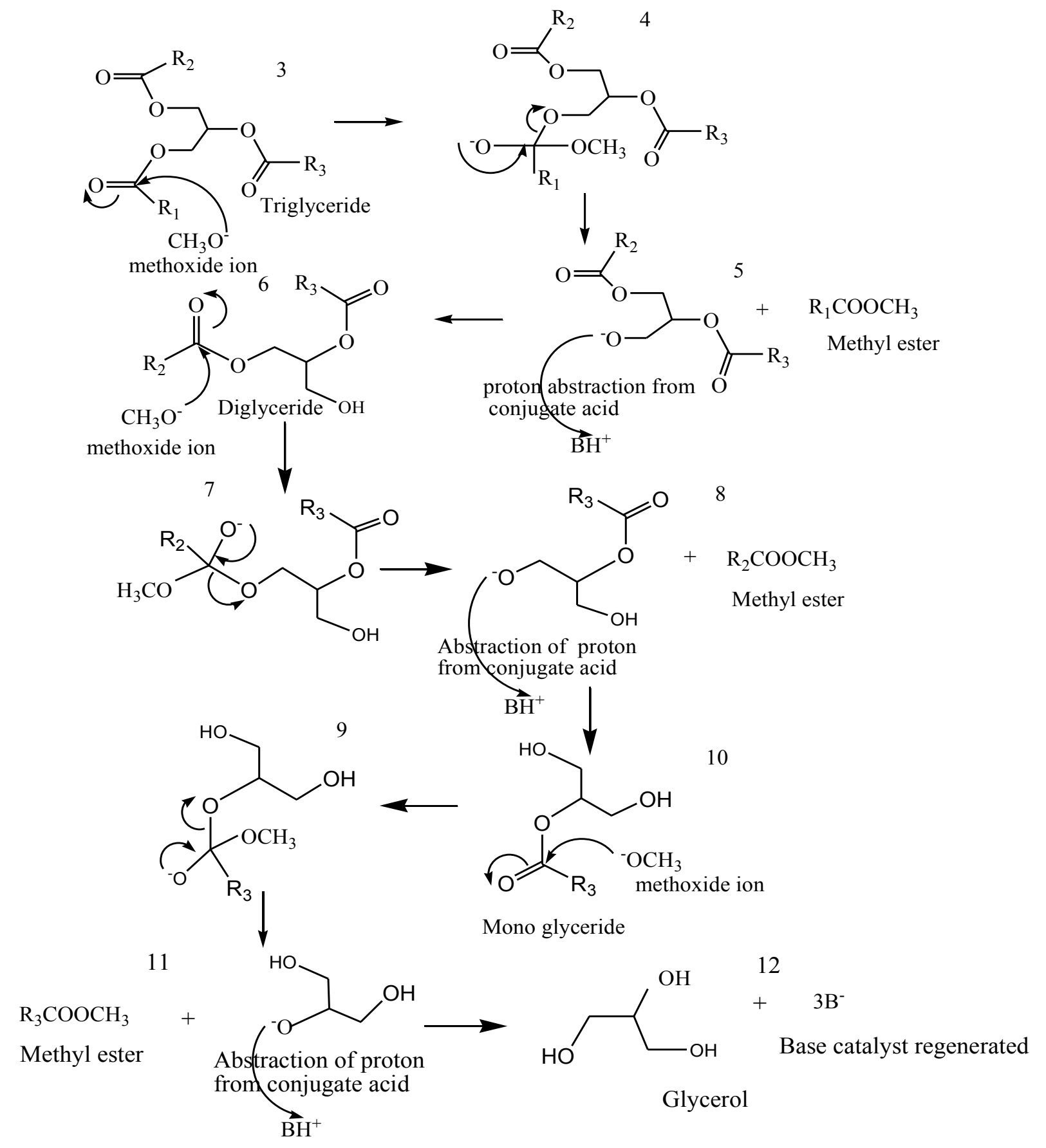

Figure 2. Reaction Mechanism for base catalyzed trans-esterification.

\section{OBJECTIVES OF THE STUDY}

\section{1. General objective}

The general objective of this study was to investigate the chemical composition, characterization and to determine the energy content for the renewable energy source (biodiesel) produced from non-edible Ethiopian seeds' particularly castor seed (Ricinus communis) using homogeneous catalysis. 


\section{2. Specific objectives}

In order to address the aforementioned general objective, the following specific objectives were formulated:

$>$ Extraction of the crude oil from the kernels of the castor seeds by soxhlet apparatus using $n$ - hexane as an extracting solvent.

$>$ Determine the optimum conditions/parameters (such as reaction temperature, alcoholto-oil molar ratio, type and concentration of catalyst and reaction time) for the production of maximum amount of biodiesel.

$>$ Determine the physicochemical properties of crude oil extract, oil blends, biodiesel and biodiesel blends such as acid value, density, kinematic viscosity, iodine value and higher heating values.

$>$ Compare the physicochemical properties of castor oil, oil blends, biodiesel and biodiesel blends with the biodiesel standards (ASTM D6751 and EN14214 standards).

$>$ Analyze the chemical composition of the biodiesel using chromatographic and spectroscopic techniques such as gas chromatography coupled with mass spectrometry (GC-MS).

\section{MATERIALS AND METHODS}

The experimental work was done in the organic laboratory of Department of Chemistry, Mekelle University.

\section{1. Plant materials}

\section{1. 1. Castor seed collection}

Fresh castor seeds were collected from Adigrat Eastern Tigray which is 898 km's far away from Addis Abeba toward north.

\section{2. Chemicals and reagents}

Methanol (99\%), sodium hydroxide, sulphuric acid (98\%), n-hexane, sodium thiosulfate, phenolphthalein, ethanol (96\%), anhydrous sodium sulphate, and potassium hydroxide.

\section{3. Instrumentations}

Soxhlet apparatus, Rotary evaporator, GC-MS, bomb calorimeter, viscometer, hot plate thermometer, round bottom flask, separatory funnel, mortar and pestle were used.

\section{4. Experimental design}

\section{4. 1. Experimental Treatments}

Two types of catalysts, acidic catalyst $\left(\mathrm{H}_{2} \mathrm{SO}_{4}\right)$ and basic catalyst $(\mathrm{NaOH})$ were used at different reaction temperatures to study which catalyst is better for optimum biodiesel production from castor oil. In addition to this blending of castor oil and biodiesel were conducted with petroleum diesel. Finally the physicochemical properties of the castor oil, biodiesel, blended biodiesel and blended castor oil were determined and compared with a set 
of parameter according to European Standard, EN 14214 and American standard test and material, ASTM6751 [11,12].

Table 1. Experimental treatments.

\begin{tabular}{|c|c|c|c|c|c|}
\hline $\begin{array}{c}\text { Methanol to } \\
\text { oil molar } \\
\text { ratio }\left(\mathrm{T}_{1}\right)\end{array}$ & $\begin{array}{c}\text { Temperature } \\
\text { in }{ }^{\circ} \mathrm{C}\left(\mathrm{T}_{2}\right)\end{array}$ & $\begin{array}{c}\% \mathrm{w} / \mathrm{w} \text { of } \\
\mathrm{H}_{2} \mathrm{SO}_{4} \text { to } \\
\text { oil }\left(\mathrm{T}_{3}\right)\end{array}$ & $\begin{array}{c}\% \mathrm{w} / \mathrm{w} \text { of } \\
\mathrm{NaOH} \text { to } \\
\text { oil }\left(\mathrm{T}_{4}\right)\end{array}$ & $\begin{array}{c}\% \mathrm{~V} / \mathrm{V} \text { of oil to } \\
\text { petroleum } \\
\text { diesel ratio }\left(\mathrm{T}_{5}\right)\end{array}$ & $\begin{array}{c}\% \mathrm{~V} / \mathrm{V} \\
\text { biodiesel/ } \\
\text { petroleum } \\
\text { diesel ratio }\left(\mathrm{T}_{6}\right)\end{array}$ \\
\hline $3: 1$ & 45 & 3 & 1 & $20: 80=\mathrm{C} 20$ & $10: 90=\mathrm{B} 10$ \\
\hline $6: 1$ & 55 & 4 & 2 & $25: 75=\mathrm{C} 25$ & $20: 80=\mathrm{B} 20$ \\
\hline $9: 1$ & 65 & 5 & 3 & $30: 70=\mathrm{C} 30$ & $30: 70=\mathrm{B} 30$ \\
\hline
\end{tabular}

Where: $\mathrm{T}=$ treatment, $\mathrm{C}=$ castor oil, $\mathrm{B}=$ Biodiesel

\section{5. Soxhlet extraction of castor oil and Percentage yield of the oil}

The clean kernels were grounded in to powder by using pestle and mortar. After that $100 \mathrm{~g}$ of grounded kernel was loaded in to thimble in Soxhlet apparatus and extraction was carried out using $600 \mathrm{ml}$ normal hexane at $68{ }^{\circ} \mathrm{C}$ (boiling temperature of hexane) for $24 \mathrm{~h}$ in an electrical heater. The mixture of the extracted oil and the hexane was separated by rotary evaporator and the percentage of the oil was calculated by the following formula:

$$
\% \text { Oil = Mass of Oil x 100/ Mass kernel }
$$

\section{6. Determination of the physicochemical properties}

Density, specific gravity, kinematic viscosity, acid value, saponification value, iodine value, peroxide value and higher heating value of the castor oil, castor oil blend, biodiesel and biodiesel blendes were determined.

\section{RESULTS AND DISCUSSION}

\section{1. Yield}

From $4 \mathrm{kgs}$ of castor seed $3 \mathrm{kgs}$ of kernels and one gram shells were obtained. From this $75 \%$ of the mass of the raw castor seed was kernel and the remaining $25 \%$ was the mass of the shell.

From these kernels 2.1 liters of crude oil with a density of $953.2 \mathrm{~kg} / \mathrm{m}^{3}$ was obtained. Then Mass of oil $=$ density of oil $\times$ volume of oil $=953.2 \mathrm{~kg} / \mathrm{m}^{3} \times 2.1 \mathrm{~L} \mathrm{x} 1 \mathrm{~m}^{3} / 1000 \mathrm{~L}=2 \mathrm{~kg}$ of oil \% oil extracted $=$ Mass of oil x100/ Mass of seed $=(2 \mathrm{~kg} \mathrm{x} \mathrm{100)} / 3 \mathrm{~kg}=66.67 \%$

\section{2. Physicochemical properties}

The biodiesel, biodiesel blends and castor oil blends had lower specific gravity, density and kinematic viscosity compared to castor oil (Table 2). This is due to the fact that castor oil contains three esters combined together while the biodiesel contains a single ester.

Conversely biodiesel, biodiesel blends and castor oil blends had higher heating value than the castor oil. The main reason for the increased higher heating value of biodiesel, 
biodiesel blendes and castor oil blends is due their lower specific gravity and kinematic viscosity. Besides to this the higher heating values of the biodiesel blends were larger than the biodiesel but lower than the petroleum diesel. This is due further reduction in specific gravity and kinematic viscosity of the blends. The carbon residue of the oil was higher than the biodiesel, biodiesel blends, castor oil blends and petroleum diesel. This is due to the fact that there will be no complete combustion as a result of the higher kinematic viscosity of the oil. Even though the kinematic viscosity of petroleum diesel was lower than the biodiesel, biodiesel blends and castor oil blends its carbon residue was higher. This is because of the incomplete combustion of the non-oxygenated hydrocarbons and aromatic compounds in petroleum diesel. The higher heating value and carbon residue were increasing as the amount of the petroleum diesel increases in the blend. The main reason for the increasing of the higher heating value is the decrease of specific gravity and kinematic viscosity of the blends. The higher heating values of biodiesel blends and castor oil blends lie between the heating values of their constituents.

Generally the physicochemical properties of the biodiesel, biodiesel blends and castor oil blends (up to $\mathrm{C}_{25}$ ) lie within the biodiesel standard limits except kinematic viscosity for B100 (i.e $8.02 \mathrm{~mm}^{2} / \mathrm{sec}$ ). This is out of the range of the ASTMD6751 and EN14214 biodiesel standards. Hence to decrease the kinematic viscosity of the biodiesel it is necessary to blend with petroleum diesel. The blended biodiesel and castor oil blends kinematic viscosities (B30, $\mathrm{B} 20, \mathrm{~B} 10, \mathrm{C}_{20}$ and $\mathrm{C}_{25}$ ) were within the biodiesel standard limits and similar physicochemical properties to petroleum diesel. Therefore these biodiesel blends and castor oil blends can be used in diesel engine to substitute petroleum diesel (Table 2).

Table 2. Physicochemical properties of castor oil, castor oil blends, biodiesel, biodiesel blend and Petroleum diesel.

\begin{tabular}{|c|c|c|c|c|c|c|c|c|c|}
\hline Properties & $\mathbf{C}_{\mathbf{1 0 0}}$ & $\mathbf{C}_{\mathbf{3 0}}$ & $\mathbf{C}_{\mathbf{2 5}}$ & $\mathbf{C}_{\mathbf{2 0}}$ & $\mathbf{B}_{\mathbf{1 0 0}}$ & $\mathbf{B}_{\mathbf{3 0}}$ & $\mathbf{B}_{\mathbf{2 0}}$ & $\mathbf{B}_{\mathbf{1 0}}$ & $\mathbf{P}_{\mathbf{1 0 0}}$ \\
\hline Specific gravity & 0.95 & 0.92 & 0.886 & 0.88 & 0.882 & 0.873 & 0.860 & 0.856 & 0.845 \\
\hline Density at $15^{\circ} \mathrm{C}$ & 950 & 920 & 886 & 88 & 882 & 873 & 860 & 856 & 845 \\
\hline $\begin{array}{c}\text { Kinamatic } \\
\text { viscosity at } 40 \\
{ }^{\circ} \mathrm{C}\end{array}$ & 180 & 14.64 & 5.89 & 5.64 & 8.02 & 4.8 & 4.5 & 3.78 & 2.86 \\
\hline Acid value & 0.24 & 0.22 & 0.08 & 0.062 & 0.08 & 0.002 & $1.8 \times 10^{3}$ & $3.4 \times 10^{4}$ & ----- \\
\hline \begin{tabular}{c} 
Free fatty acid \\
\hline $\begin{array}{c}\text { Saponification } \\
\text { value }\end{array}$
\end{tabular} & 0.32 & 0.11 & 0.04 & 0.031 & 0.04 & 0.001 & $9 \times 10^{-4}$ & $1.7 \times 10^{-4}$ & ----- \\
\hline Flash point & 140 & 30.24 & 23.62 & 18.84 & 11.54 & 3.79 & 1.068 & 0.276 & ---- \\
\hline $\begin{array}{c}\text { Higher heating } \\
\text { value }\end{array}$ & 39 & 39.98 & 41 & 41.86 & 40.7 & 43.3 & 44.90 & 44.93 & 45.5 \\
\hline Peroxide value & 20 & 14.4 & 11.3 & 9.86 & 28 & 24.4 & 22.2 & 20.28 & ----- \\
\hline Iodine value & 76 & 64 & 54.32 & 49.86 & 76 & 56 & 51 & 43 & ----- \\
\hline Carbon residue & 0.09 & 0.053 & 0.0498 & 0.0492 & 0.028 & $4.3 \times 10^{-3}$ & $5.2 \times 10^{-3}$ & $7.2 \times 10^{-3}$ & 0.049 \\
\hline Ester content & ------ & ------ & ------ & ----- & 96.7 & ------- & ------- & ------- & ----- \\
\hline
\end{tabular}




\section{3. Effect of different variables on trans-esterification process}

Table 3. Methyl ester content, as function of catalyst type and mass weight of catalyst at methanol/oil molar ratio, 9:1; reaction temperature, $55^{\circ} \mathrm{C}$; reaction time of 3 hours.

\begin{tabular}{|c|c|c|c|}
\hline $\begin{array}{c}\text { Type of } \\
\text { catalysts }\end{array}$ & $\begin{array}{c}\text { Mass weight of } \\
\text { catalyst, wt. \% }\end{array}$ & Temperature & $\begin{array}{c}\text { Methyl ester content, } \\
\text { w/w \% }\end{array}$ \\
\hline \multirow{3}{*}{$\mathrm{H}_{2} \mathrm{SO}_{4}$} & 3 & 55 & 45 \\
\cline { 2 - 4 } & 4 & 55 & 46 \\
\hline \multirow{3}{*}{$\mathrm{NaOH}$} & 5 & 55 & 46.4 \\
\cline { 2 - 4 } & 1 & 55 & 90 \\
\cline { 2 - 4 } & 2 & 55 & 94 \\
\hline
\end{tabular}

Table 4. Methanol /oil molar ratio influence on the amount of methyl ester content, at fixed reaction temperature $\left(65^{\circ} \mathrm{C}\right)$, reaction time 3 hours and mass Weight of catalysts.

\begin{tabular}{|c|c|c|c|}
\hline $\begin{array}{l}\text { Methanol to oil } \\
\text { molar ratio }\end{array}$ & catalyst & $\% \mathrm{~W}$ of catalyst & $\begin{array}{c}\text { w/w } \% \text { of methyl } \\
\text { ester content }\end{array}$ \\
\hline $3: 1$ & \multirow{3}{*}{$\mathrm{H}_{2} \mathrm{SO}_{4}$} & \multirow{3}{*}{3 wt. $\%$} & 47 \\
\hline $6: 1$ & & & 49.8 \\
\hline $9: 1$ & & & 52 \\
\hline $3: 1$ & \multirow{3}{*}{$\mathrm{NaOH}$} & \multirow{3}{*}{1 wt. $\%$} & 75 \\
\hline $6: 1$ & & & 96.7 \\
\hline $9: 1$ & & & 94 \\
\hline
\end{tabular}

Table 5. Influence of the reaction temperature on the methyl ester content, catalyst type, $\mathrm{NaOH}$; catalyst amount, 1 wt. \%; methanol/oil molar ratio, 9:1.

\begin{tabular}{|c|c|c|c|}
\hline $\begin{array}{c}\text { Temperature } \\
\text { in }{ }^{\circ} \mathbf{C}\end{array}$ & Type of catalyst & $\begin{array}{c}\text { Mass weight \% } \\
\text { catalyst }\end{array}$ & $\begin{array}{c}\text { Methyl ester } \\
\text { content, w/w \%o }\end{array}$ \\
\cline { 1 - 1 } 45 & & & 89 \\
\cline { 1 - 1 } 55 & \multirow{2}{*}{$\mathrm{NaOH}$} & 1 wt.\% & 92 \\
\cline { 1 - 1 } 65 & & & 94 \\
\hline
\end{tabular}


4. 4. GC-MS analysis of biodiesel prepared from castor oil

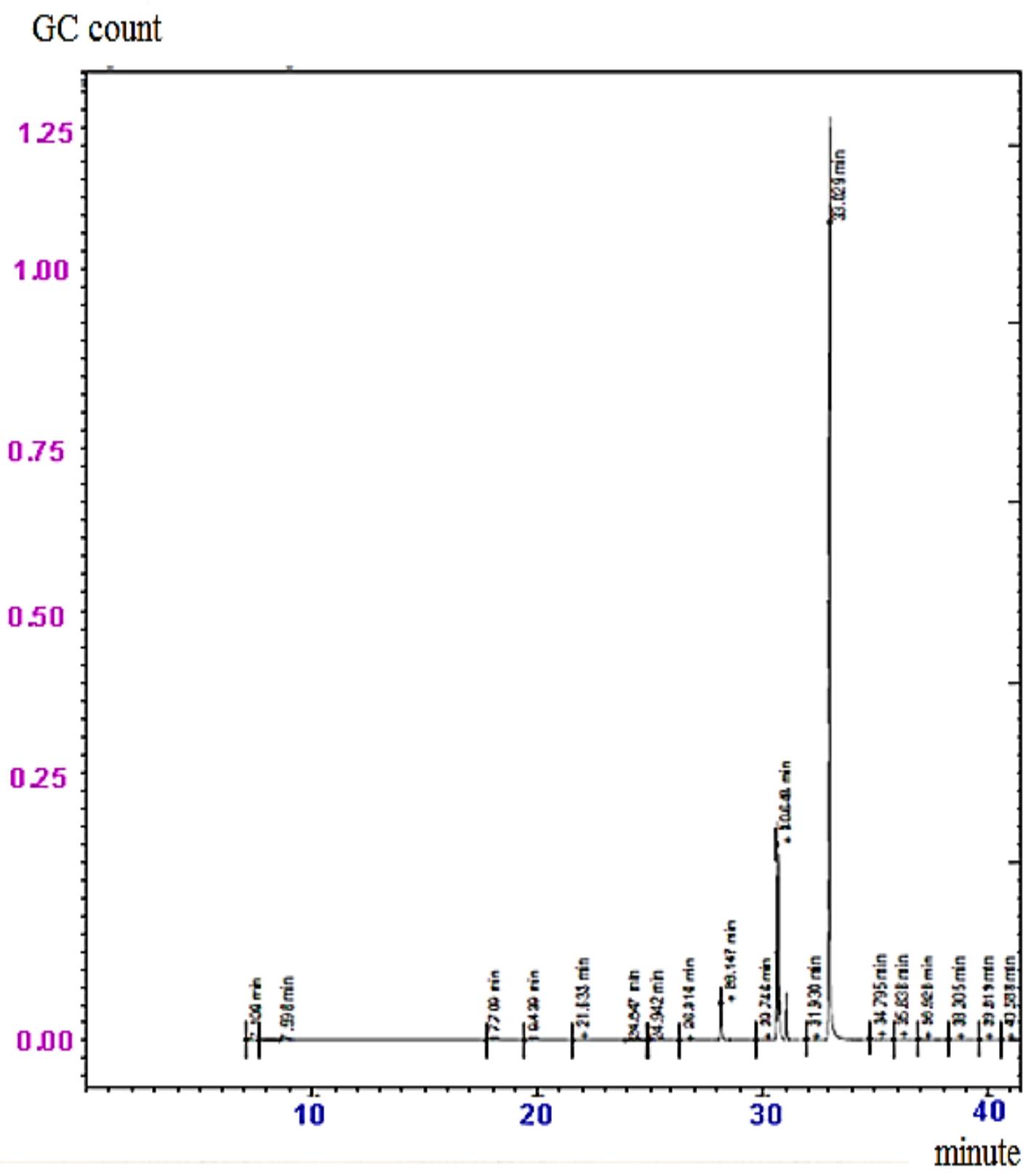

Figure 3. GC Chromatogram of FAMEs of castor oil. 
Table 6. Chemical composition of FAMEs of castor oil by GC-MS analysis.

\begin{tabular}{|c|c|c|c|c|c|}
\hline No & Name of compound & $\begin{array}{c}\text { Molecular } \\
\text { formula }\end{array}$ & $\begin{array}{c}\text { Molecular } \\
\text { weight }\end{array}$ & $\begin{array}{c}\text { Retention } \\
\text { time (min) }\end{array}$ & $\begin{array}{c}\text { Amount } \\
\text { \% }\end{array}$ \\
\hline 1 & $\begin{array}{c}\text { 9-Octadecenoic acid, } \\
12-\text {-acetyloxy)-methyl ester }\end{array}$ & $\mathrm{C}_{21} \mathrm{H}_{38} \mathrm{O}_{4}$ & 354 & 29.746 & 0.2 \\
\hline 2 & $\begin{array}{c}\text { Heptadecanoicacid, } \\
\text { 14-methyl-methyl ester }\end{array}$ & $\mathrm{C}_{19} \mathrm{H}_{38} \mathrm{O}_{2}$ & 298 & 28.147 & 11.0 \\
\hline 3 & $\begin{array}{c}\text { Octadecanoic acid, } \\
\text { 14-methyl-methyl ester }\end{array}$ & $\mathrm{C}_{20} \mathrm{H}_{40} \mathrm{O}_{2}$ & 312 & 30.648 & 39.4 \\
\hline 4 & $\begin{array}{c}\text { Pentadecanoic acid, } \\
\text { 14-methyl-methyl ester }\end{array}$ & $\mathrm{C}_{17} \mathrm{H}_{34} \mathrm{O}_{2}$ & 270 & 33.029 & 40.5 \\
\hline 5 & $\begin{array}{c}\text { 8-Octadecenoic acid, } \\
\text { methyl ester (E)- }\end{array}$ & $\mathrm{C}_{19} \mathrm{H}_{36} 0_{2}$ & 296 & 30.738 & 8.9 \\
\hline 7 & $\begin{array}{c}\text { Cyclo propane octanoic acid, } \\
\text { 2-octyl-,methyl ester }\end{array}$ & $\mathrm{C}_{20} \mathrm{H}_{38} \mathrm{O}_{2}$ & 310 & 31.932 & Trace \\
\hline 8 & $\begin{array}{c}9,12,15-\text {-Octadecatrienoicacid, } \\
2,3-\text {-dihydroxy methyl ester }\end{array}$ & $\mathrm{C}_{19} \mathrm{H}_{32} \mathrm{O}_{4}$ & 324 & 29.383 & Trace \\
\hline $\begin{array}{c}\text { Hexadecanoic acid, } \\
15-\text { methyl- methyl esters }\end{array}$ & $\mathrm{C}_{18} \mathrm{H}_{36} \mathrm{O}_{2}$ & 284 & 32.183 & Trace \\
\hline
\end{tabular}

\section{5. Analysis of mass fragmentation of FAMEs}

The mass fragmentation for the major fatty acid methyl ester pentadecanoic acid, 14methyl-methyl ester (40.5\%) from the eight methyl esters identified by GC-MS were worked out and from the 10 prominent peaks of it, one is the molecular ion peak $\left(\mathrm{M}^{+}\right)$at $\mathrm{m} / \mathrm{z}=270$ which is abundant and formed by removing of one electrons from the molecule. The most abundant peak is at $\mathrm{m} / \mathrm{z}=74$ which is also called the base peak. This fragment results from a McLafferty rearrangement, which is formed by transferring of $\gamma$-hydrogen atom from the acid moiety to the carbonyl oxygen through a six membered cyclic transition state and the $\mathrm{C}_{2}-\mathrm{C}_{3}$ bond cleavage (figure 4). The peak at $\mathrm{m} / \mathrm{z}=227$ was due to loss of an isopropyl radical from the molecular ion to form a fragment of the type $\left[\left(\mathrm{CH}_{2}\right)_{12} \mathrm{CO}_{2} \mathrm{CH}_{3}\right]^{+}$(Figure 4). Besides to the above mentioned mass fragmentation peaks of Pentadecanoic acid, 14-methyl- methyl ester several additional mass fragment peaks were observed.

These were $\mathrm{m} / \mathrm{z}$ ratios of $87,55,43,41,143,69$, and so on. The peak at $\mathrm{m} / \mathrm{z}=87$ is due to bond cleavage between $\mathrm{C}_{3}$ and $\mathrm{C}_{4}$ and the formation of $\left[\left(\mathrm{CH}_{2}\right)_{2} \mathrm{CO}_{2} \mathrm{CH}_{3}\right]^{+}$. The peak at $\mathrm{m} / \mathrm{z}$ $=143$ is due to bond cleavage between $\mathrm{C}_{7}$ and $\mathrm{C}_{8}$ and the formation of $\left[\left(\mathrm{CH}_{2}\right)_{6} \mathrm{CO}_{2} \mathrm{CH}_{3}\right]^{+}$. The peak at $\mathrm{m} / \mathrm{z}=43$ is due to bond cleavage between $\mathrm{C}_{13}$ and $\mathrm{C}_{14}$ and the formation of $\mathrm{CH}_{3}$ ${ }^{+} \mathrm{CHCH}_{3}$. The peak at $\mathrm{m} / \mathrm{z}=41$ is due to bond cleavage between $\mathrm{C}_{13}$ and $\mathrm{C}_{14}$ as a result there is a formation of $\mathrm{CH}_{3} \mathrm{CHCH}_{3}$ radical. This radical further undergo fragmentation and two hydrogen atoms were removed from it and the peak $\mathrm{m} / \mathrm{z}=41$ was appeared due to the formation of $\mathrm{CH}_{2}={ }^{+} \mathrm{CCH}_{3}$. The peak at $\mathrm{m} / \mathrm{z}=55$ is due to bond cleavage between $\mathrm{C}_{12}$ and $\mathrm{C}_{13}$ leading to the formation of $\mathrm{CH}_{2} \mathrm{CH}_{2} \mathrm{CH}_{2} \mathrm{CH}_{3}$ radical. This radical further undergo fragmentation and two hydrogen atoms were removed from it, the peak $\mathrm{m} / \mathrm{z}=55$ appeared due to the formation of ${ }^{+} \mathrm{CH}_{2} \mathrm{CH}=\mathrm{CHCH}_{3}$. The mass fragmentations of Pentadecanoic acid, 14-methyl-methyl ester were diagrammatically described as follows (Figure 5). 


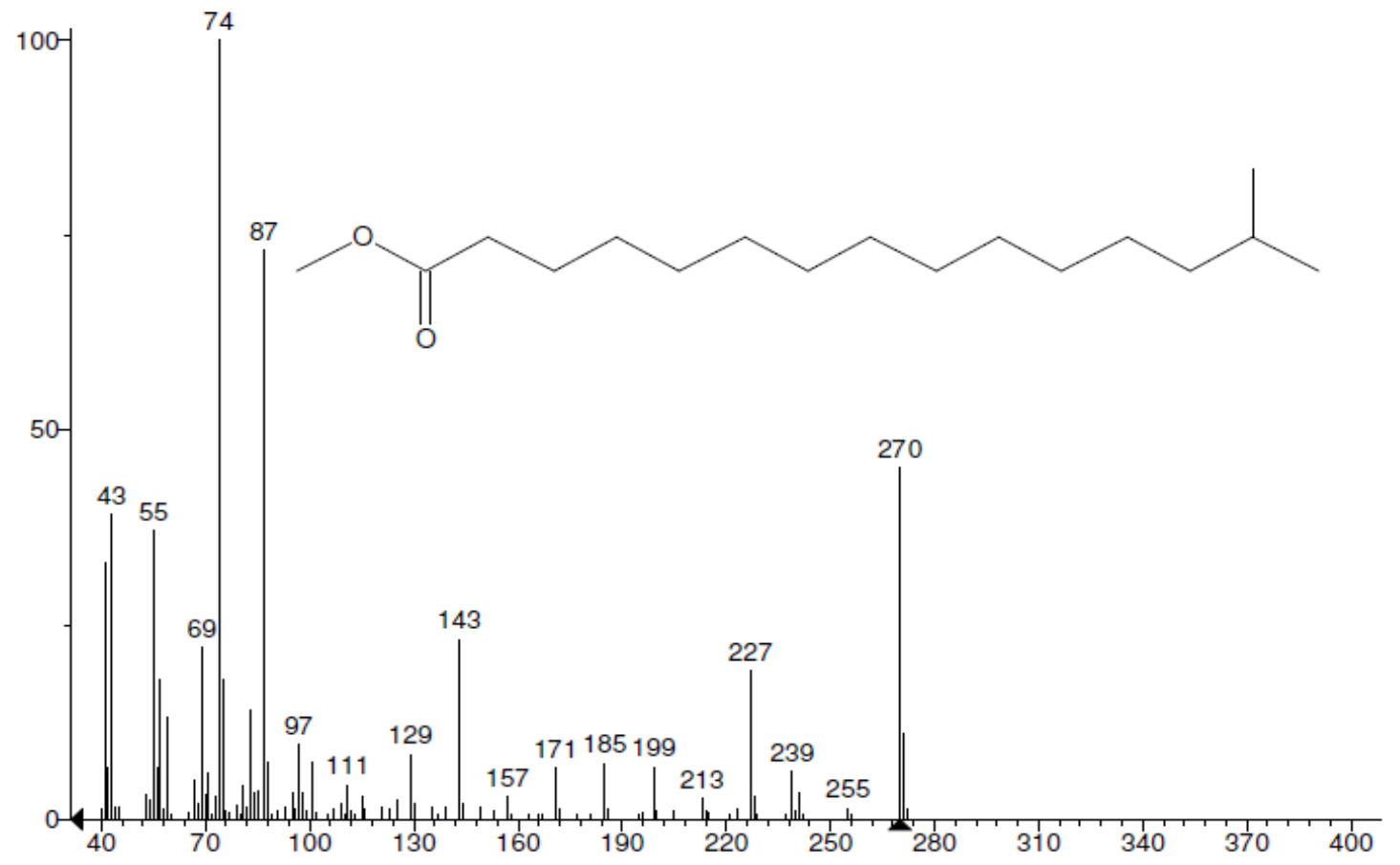

Figure 4. Mass spectra of Pentadecanoic acid, 14-methyl- methyl ester.

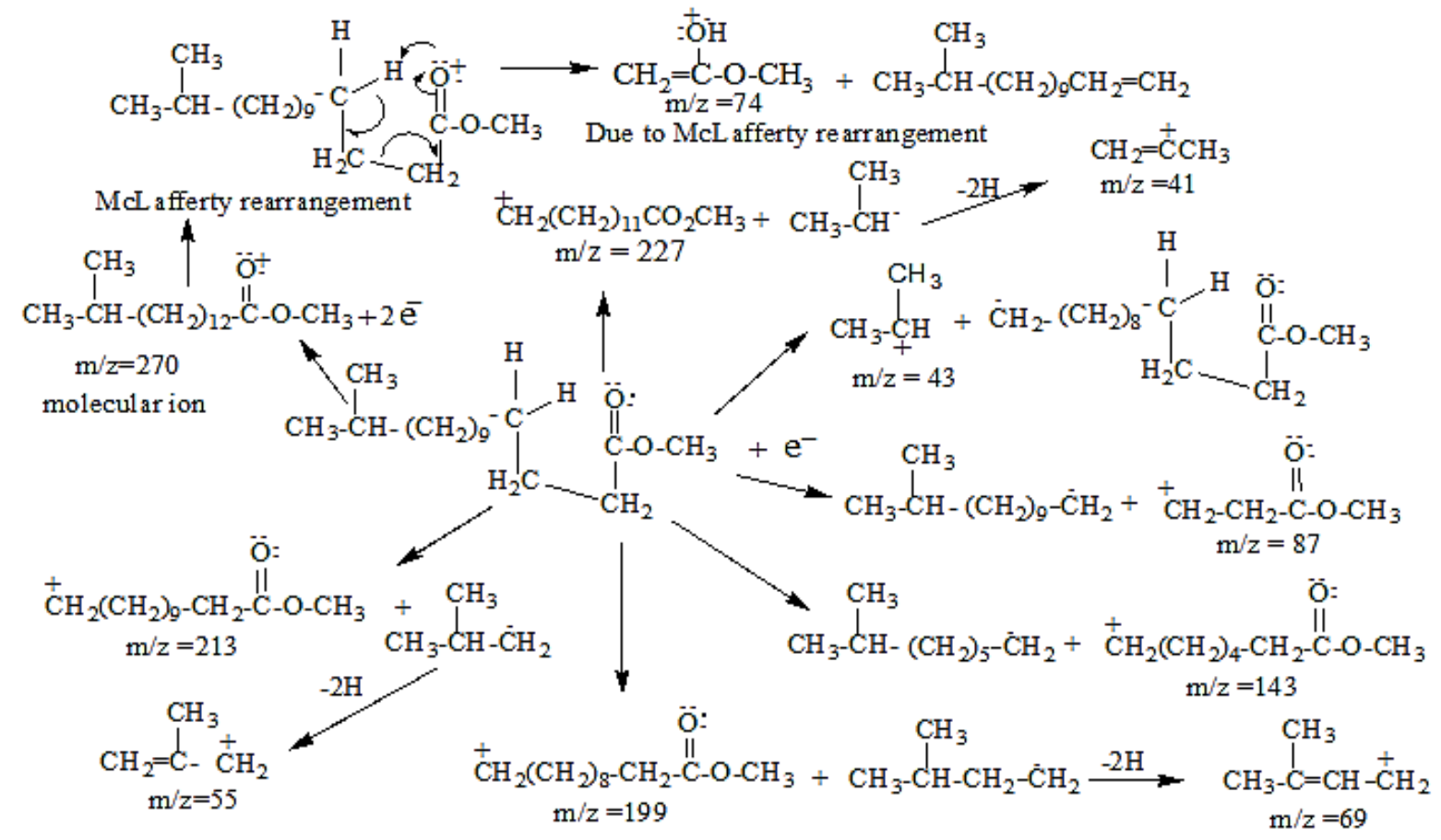

Figure 5. Mass fragmentation of Pentadecanoic acid, 14-methyl- methyl ester. 


\section{CONCLUSIONS}

In this study, the four trans-esterification parameters affecting the yield of biodiesel such as reaction temperature, molar ratio of methanol to oil, type and mass weight of catalyst have been studied. In addition to this the oil, oil blends, biodiesel and biodiesel blends have been analyzed by employing analysis of physicochemical parameters and chromatographic technique coupled with spectroscopic technique (GC-MS) for identification of their chemical compositions. Our result indicates that all the process variables have significant effect on the yield of the biodiesel and a maximum of biodiesel yield $(96.7 \%)$ was obtained from raw castor oil by using the optimum process parameters such as methanol to oil molar ratio of $6: 1$, $1 \%$ of $\mathrm{NaOH}$, reaction temperature of $65^{\circ} \mathrm{C}$ and reaction time of 3 hours. Therefore, it can be concluded that $\mathrm{NaOH}$ is an effective catalyst for the production of biodiesel from castor oil via homogeneous trans-esterification. The main advantage of trans-esterification reaction conducted for biodiesel production in this study was to lower the high kinematic viscosity of the oil. The kinematic viscosity of the oil was reduced from $180 \mathrm{~mm}^{2} / \mathrm{sec}$ to $8.02 \mathrm{~mm}^{2} / \mathrm{sec}$. All the physicochemical properties of the biodiesel produced from castor were determined and meet the ASTM specification except viscosity for B100 which is $8.02 \mathrm{~mm}^{2} / \mathrm{sec}$. Therefore it was needed to blend with diesel fuel to bring it to the limits for biodiesel.

\section{Recommendation}

In this research, the biodiesel production process was done by using only homogeneous catalysts and methanol. Therefore, further research is warranted to check which catalyst (homogeneous or heterogeneous) is more effective and gives optimum amount of biodiesel.

Since enough ethanol will be available in Ethiopia in the future due to plantation of many sugar factories, future research on investigation of biodiesel production using heterogeneous catalyst and ethanol is recommended.

\section{ACKNOWLEDGEMENT}

I would like to thank the Almighty GOD for giving me the strength and wisdom to successfully complete this research for his protection and strength, and an ever present help in the entire situation and challenge that I face. Moreover, I would like to express my heartfelt appreciation and thanks to my advisor Dr. Afework Mulugeta for his sustainable and appreciable guidance, tireless advising, for sharing his knowledge, skill and experience for the successful completion of this research.

Finally, I would like to express my deepest gratitude to the organizing committee of Hawassa University for giving me a chance to present my research on the symposium on adaptation for climate change for water, energy and Environment held on June 27-28 at Hawassa University.

\section{References}

[1] Ma F., Hanna M. A., Bio resource Technology 70 (1999) 1-15.

[2] Coronado C. R., Decarvalho J. A., Yoshioka J. T., Silveira J. L., Applied Thermal Engineering 29 (2009) 1887-1892.

[3] Knothe G., Sharp C. A., Ryan T. W., Energy \& Fuels 20 (2006) 403-408.

[4] Pandey A. (2009). Handbook of Plant-based Biofuels; CRC Press Taylor \& Francis Group: Boca Raton, FL. 
[5] Lam M. K., Lee K. T., Mohamed A. R., Biotechnology Advances 28 (2010) 500-518.

[6] Georgogianni K. G., Katsoulidis A. K., Pomonis P. J., Manos G., Kontominas M. G., Fuel Processing Technology 90 (2009) 1016-1022.

[7] Thenes P. (2007). Biofuels and commodity markets palm oil focus, FAO, Commodities and Tread Division.

[8] Butler R. A. (2006). Why is oil palm replacing tropical rain forests?

[9] Scholz V., da Silva J. N., Biomass and Bio energy 32 (2008) 95-100.

[10] Balat M., Balat H., Applied Energy 87 (2010) 1815-1835.

[11] ASTM Standard specification for biodiesel fuel (B100) blend stock for distillate fuels. In: Annual Book of ASTM Standards, ASTM Press, West Conshohocken, Method D6751, 2008.

[12] European Committee for Standardization, Automotive fuels fatty acid methyl esters (FAME) for diesel engines requirements and test methods. European Committee for Standardization Press, Brussels, Method EN 14214: 2003. 